\title{
VIRULENCE OF ORAL FUSOBACTERIUM NUCLEATUM FROM HUMANS AND NON-HUMAN PRIMATES IN MICE
}

\author{
Elerson Gaetti-Jardim Júnior; Maria C. Rui Luvizotto; Mario J. Avila-Campos* \\ Departamento de Microbiologia, Instituto de Ciências Biomédicas, Universidade de São Paulo, São Paulo, SP, Brasil
}

Submitted: June 11, 1999; Returned to authors for corrections: March 24, 2000; Approved: April 20, 2000

\begin{abstract}
The lethal action in Balb/c mice of 80 oral Fusobacterium nucleatum recovered from patients with adult periodontitis, healthy subjects or Cebus apella monkeys was studied. Mice were inoculated intraperitoneally with each bacterial inoculum of $5 \times 10^{8} \mathrm{CFU} / \mathrm{ml}$. All the clinical isolates induced weight and coordinated movements loss. Pathological alterations in liver, CNS, heart, and kidney with inflammatory reactions or vascular congestion were observed. Of all the tested $F$. nucleatum isolates, $61.2 \%$ from periodontal patients, $57.1 \%$ from healthy subjects and $60 \%$ from monkeys, were capable of killing the mice in $48 \mathrm{~h}$. The clinical isolates were significantly more pathogenic than $F$. nucleatum ATCC 10953 or ATCC 25586. B. fragilis ATCC 23745 showed lethality against control mice. Our results suggest that LPS could be involved in lethal action against mice and it may play an important role in producing tissue damage or death of mice.
\end{abstract}

Key words: Fusobacterium nucleatum, pathogenesis, human and non-human primates

\section{INTRODUCTION}

Anaerobic microflora comprise a large percentage of the oral and gut indigenous microbiota. Anaerobes, particularly Gram-negative rods, possess potentially pathogenic factors, which appear to be related to several pathological conditions, such as periodontal diseases.

The genus Fusobacterium is the second most frequently recovered anaerobic microbial group in human and animal microflora (1). Some species, particularly $F$. nucleatum, have been involved in monomicrobial and mixed infections such as sinusitis, pelvic infections, osteomyelitis, lung abscesses and periodontal diseases (2-4).

F. nucleatum is able to produce volatile sulfur compounds (5-6), butyric and propionic acids (7), activate lymphocytes (8), and adhere to oral epithelial cells, erythrocytes, fibroblasts, lymphocytes, polymorphonuclear leukocytes, collagen IV and laminin (9-12). Many of these organisms may lead to cellular damage or dissemination of pathogens into the host. In vitro assays have shown that Porphyromonas gingivalis, Actinobacillus actinomycetemcomitans, Campylobacter rectus, Treponema denticola and $F$. nucleatum have significant pathogenic potential (13).

Using animal models, Haffajee and Socransky (14) have suggested a bacterial etiology of periodontal disease. Madden and Caton (15) and Schou et al. (16) have shown that after removal of plaque by mechanical means or using antibiotics, gingivitis and destructive periodontal disease in dogs or primates can be prevented.

The pathogenic potential of $F$. nucleatum has been studied in vitro $(7,14,33)$. However, there are few reports on virulence of this microorganism recovered from humans and Cebus apella monkeys, using animal models. The aim of this study was to evaluate the virulence of oral F. nucleatum from human and non-human primate origin, in mice.

\footnotetext{
* Corresponding author. Mailing address: Departamento de Microbiologia, Instituto de Ciências Biomédicas II, Universidade de São Paulo, CEP 05508-900, São Paulo, SP, Brasil. Fax: (+5511) 3818-7354. E-mail: mariojac@icb.usp.br
} 


\section{MATERIALS AND METHODS}

\section{Microorganisms}

Forty nine $F$. nucleatum isolates recovered from 30 adult periodontitis patients with periodontal pockets deeper than 5 $\mathrm{mm}$ and active bone loss, and 21 from 20 healthy individuals (Clinic of Periodontology, University of São Paulo, SP, Brazil), and 10 from 10 Cebus apella monkeys (Centro de Procriação do Macaco Prego, São Paulo, SP, Brazil) were examined. Reference strains F. nucleatum ATCC 10953 and ATCC 25586, and Bacteroides fragilis ATCC 23745, were included as controls.

Samples were collected from periodontal pockets (patients) and gingival crevices (healthy subjects and monkeys) (17). The samples were plated onto Omata and Disraely selective agar and brain heart infusion agar (BHIA, Difco) supplemented with $0.5 \%$ yeast extract (Difco) and 5\% defibrinated sheep blood. The identification of the isolates at species level was done using biochemical tests (18-19).

Bacteria were grown in BHI broth supplemented with 0.5\% yeast extract, under anaerobic conditions $\left(90 \% \mathrm{~N}_{2} / 10 \% \mathrm{CO}_{2}\right)$, at $37^{\circ} \mathrm{C}$, for $48 \mathrm{~h}$. Cells were harvested by centrifugation at 3,000 $\mathrm{xg}\left(8 \mathrm{~min}, 4^{\circ} \mathrm{C}\right)$ and washed three times with phosphate-buffered saline (PBS, $\mathrm{pH}$ 7.4), and resuspended in PBS to give a concentration of $5 \times 10^{8} \mathrm{CFU} / \mathrm{ml}$, as determined by $\mathrm{OD}_{550 \mathrm{~nm}}$ of 0.7 (DME-21 spectrophotometer, Digimed, SP, Brazil). The purity of the culture was determined by plating and Gramstaining.

\section{Experimental animals}

Five weeks old male Balb/c mice, weighing 25 - 30g, were obtained from the Breeding Unit for Isogenic Mice of the Instituto de Ciências Biomédicas, University of São Paulo, São Paulo, SP, Brazil. The animals were used within one week after receiving.

Prior to injection, the abdominal region of mice was shaved and an antisepsis with $77 \%(\mathrm{v} / \mathrm{v})$ ethanol was performed. $0.1 \mathrm{ml}$ of each bacterial inoculum $\left(5 \times 10^{8} \mathrm{CFU} / \mathrm{ml}\right)$ was inoculated intraperitoneally using a tuberculin syringe. For control of microbial viability, $0.1 \mathrm{ml}$ aliquots of each bacterial culture were inoculated in thioglycolate broth w/o dextrose or indicator 135$\mathrm{C}$ (Difco Laboratories), and incubated at $37^{\circ} \mathrm{C}$, for 7 days (20). Control mice were inoculated with $0.1 \mathrm{ml}$ of PBS.

After inoculation, local and systemic responses of the mice were observed daily for 7 days. The animals were checked at 8 $\mathrm{h}$ intervals for death or signs of disease. Moribund animals were watched closely and autopsied immediately after death. Then, liver, lung, spleen, kidney, intestine (small and large), central nervous system (CNS) and heart were excised and removed, and a portion was inoculated in thioglycolate broth and incubated at $37^{\circ} \mathrm{C}$ for 7 days for recovery of the organism. A portion of each organ was submitted for histopathological examination.

\section{Influence of bacterial viability on virulence}

Isolates were grown in thioglycolate broth, inactivated by heat $\left(56^{\circ} \mathrm{C}, 30 \mathrm{~min}\right)$, harvested and washed in PBS $(3,000 \mathrm{x} \mathrm{g}$, $\left.4^{\circ} \mathrm{C}, 8 \mathrm{~min}\right) .0 .1 \mathrm{ml}$ of each bacterial suspension $\left(5 \times 10^{8} \mathrm{CFU} /\right.$ $\mathrm{ml}$ ) was inoculated intraperitoneally in mice to verify the influence of the cellular viability on the induction of host damage. The bacterial viability was confirmed by observation of growth in thioglycolate broth.

\section{Pathogenic action of supernatant}

Bacteria which showed lethality in mice were grown in fresh thioglycolate broth, and submitted to centrifugation $(3,000 \mathrm{xg}$, $\left.4^{\circ} \mathrm{C}, 8 \mathrm{~min}\right)$. The supernatant was removed, filtered through cellulose acetate membrane (Millipore, $0.22 \mathrm{~mm}$ ), and aliquots of $0.1 \mathrm{ml}$ were inoculated intraperitoneally in mice.

\section{Histopathological examination}

Organs were removed aseptically and fixed in $10 \%$ neutralbuffered formalin at room temperature for $48 \mathrm{~h}$, dehydrated and embeded in paraffin. $6 \mathrm{~mm}$ pieces were prepared, stained with hematoxylin and eosin (21) and examined by brightfield microscopy.

\section{RESULTS}

The lethality of fresh and heat-inactivated $F$. nucleatum isolates is shown in Table 1. After inoculation, all infected mice showed $10 \%$ to $20 \%$ weight loss (data not shown) and, most of the animals showed loss of coordinated movements.

In some isolates, the viability was not essential to induce lethal effects on mice, since the heat-inactivated isolates $(22.5 \%$ periodontal, $19.1 \%$ healthy and $10 \%$ monkeys isolates) were also capable to kill mice. In addition, supernatants of cultures were not capable to kill mice, but induced weight loss in 48 $(60 \%)$ animals. Neither the reference strain F. nucleatum ATCC 10953 nor ATCC 25586 were lethal to mice. However, B. fragilis ATCC 23745 killed two control mice (2.5\%).

Histopathological observation revealed deep alterations in liver and vascular system, with intense inflammatory reaction. Liver with necrotic areas (Fig. 1) and microvacuolar degenerative process in hepatocytes, and intense inflammatory reaction characterized by numerous polymorphonuclear leukocytes and mononuclear inflammatory cells on hepatic capsule were also observed (Fig. 2).

The CNS showed severe vascular congestion with haemorragic perivascular areas (Fig. 3) which indicated changes in vascular permeability. Also, the heart showed intense vascular congestion, perivascular hemorrhage and areas of suggestive degenerative process (Fig. 4). In kidney, tubular necrosis with picnotic cells and vascular congestion into glomeruli (Fig. 5) were observed. 


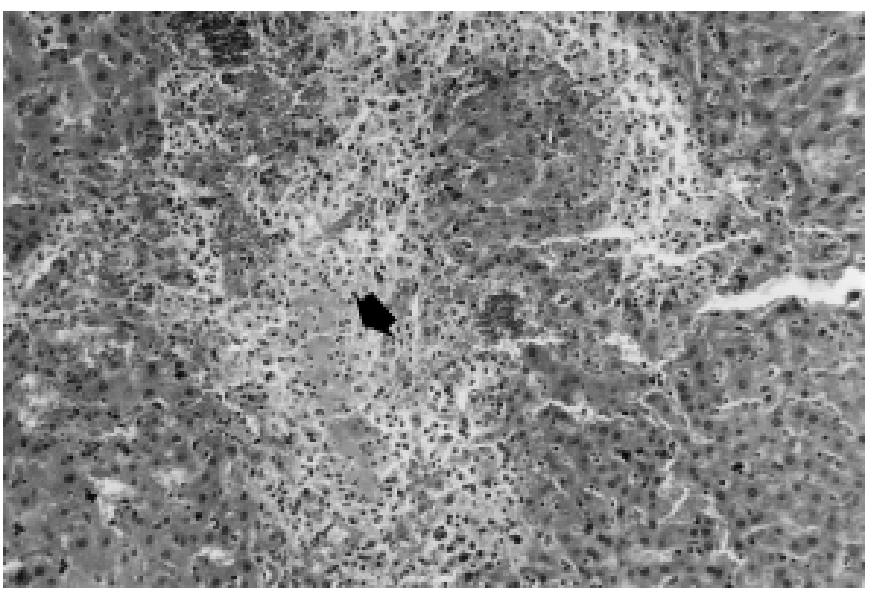

Figure 1. Histopathology of liver with a necrotic central area and vascular congestion (arrow), after injection of virulent F. nucleatum. x 63 .

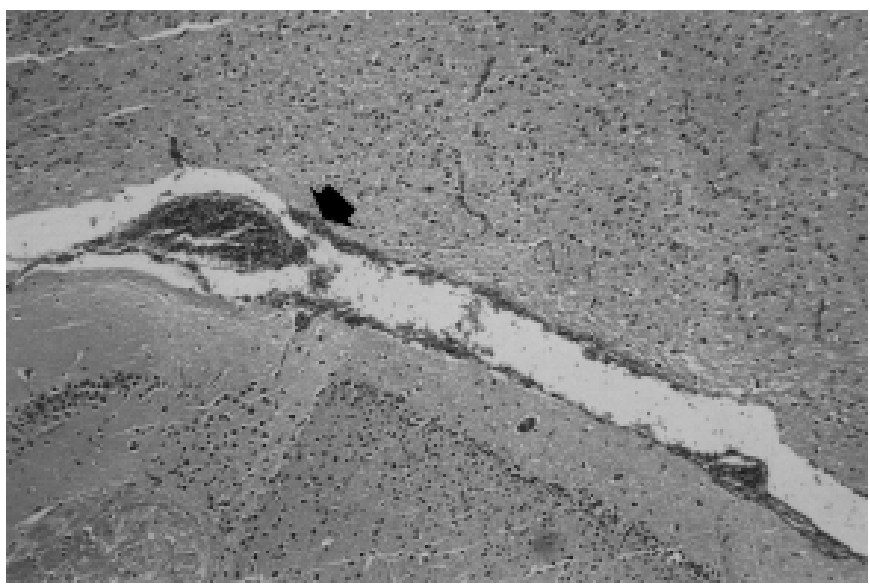

Figure 3. Vascular congestion and haemorragic areas in CNS (arrow), after injection of virulent $F$. nucleatum. x 63 .

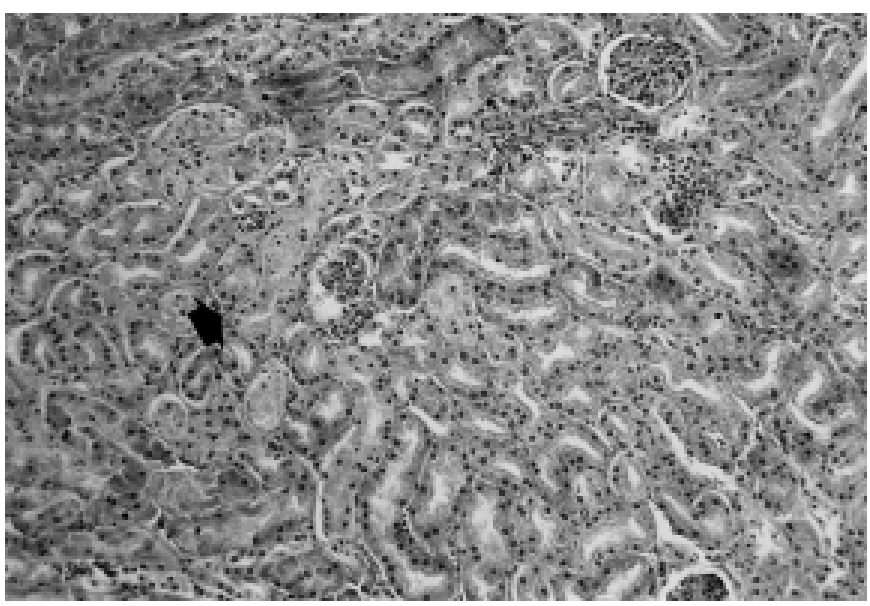

Figure 5. Vascular congestion in glomeruli and tubular necrosis areas (arrow). x 63

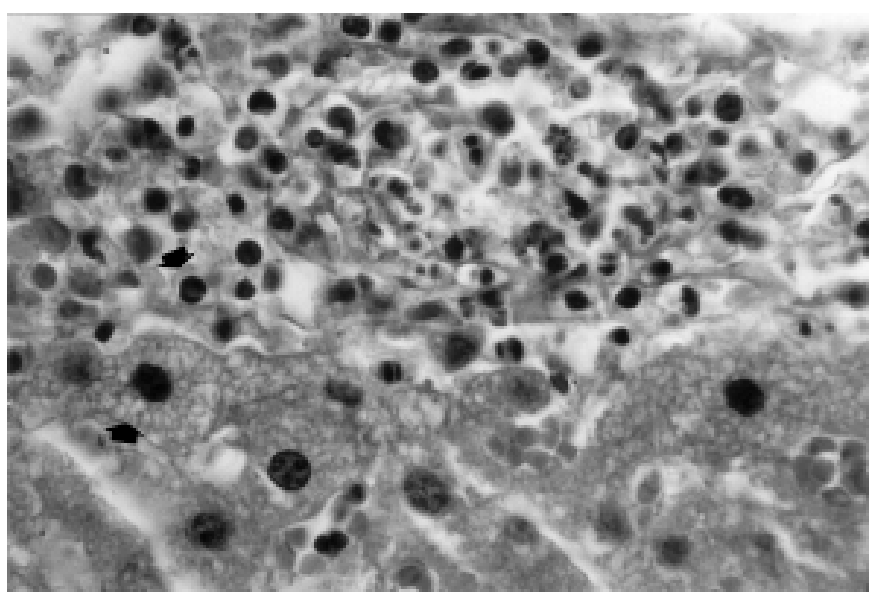

Figure 2. Microvacuolar degeneration of hepatocytes and intense inflammatory reaction (arrow), after injection of virulent $F$. nucleatum. x 160.

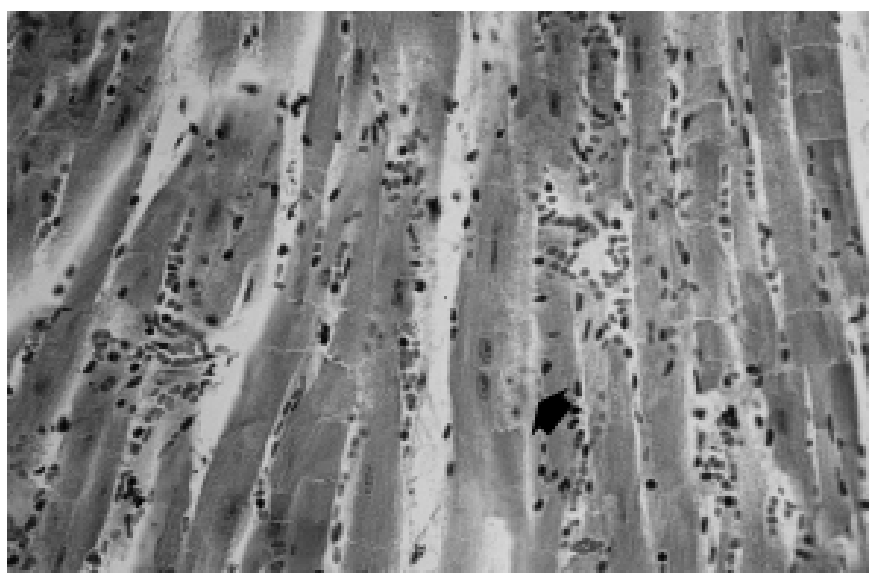

Figure 4. Cardiac tissue with degenerative areas (arrow), haemorrhage and infiltration of mononuclear cells. x 160.

Table 1. Lethal action of 80 active and inactived oral $F$. nucleatum strains from humans and monkeys on inbred Balb/c mice.

\begin{tabular}{lccccc}
\hline \multirow{2}{*}{ Samples } & \multicolumn{4}{c}{ Bacterial action* } \\
\cline { 2 - 3 } \cline { 2 - 3 } No. & \multicolumn{2}{c}{ Viable } & & \multicolumn{2}{c}{ Inactived $^{\mathrm{a}}$} \\
\cline { 2 - 3 } \cline { 5 - 6 } $\begin{array}{l}\text { Periodontal patients } \\
49\end{array}$ & 36 & 61.2 & & 11 & 22.5 \\
$\begin{array}{l}\text { Healthy subjects } \\
21\end{array}$ & 12 & 57.1 & & 4 & 19.1 \\
$\begin{array}{l}\text { C. apella } \text { monkeys } \\
10\end{array}$ & 6 & 60.0 & & 1 & 10.0 \\
\hline
\end{tabular}

*Bacteria capable of kill mice in $48 \mathrm{~h}$, after inoculation.

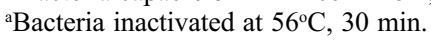


No significant histopathological alteration of lung, spleen or intestine was observed. When blood samples obtained by cardiac punctures from moribund mice were cultured, the microorganims were recovered. Surprisingly, the animals which survived for more than $48 \mathrm{~h}$ after inoculation, evolved to normality.

\section{DISCUSSION}

Historically, animal models have been invaluable for the establishment of the etiology and pathogenicity of human infectious diseases (22). The mechanism of bone breakdown in periodontal disease is still unresolved. Much is known about host factors involved in periodontal disease, but, little is known about the in situ interaction of these factors with bacterial components, and how they are related to disease progression (23).

The complexity of the bacterial ecology in the subgingival plaque and the inherent difficulties in measurement of the disease progression has made these models somewhat problematic to identify the in vitro virulence factors activity expressed by oral bacteria (24).

Intraperitoneal infection of either pure or mixed culture in an animal model should allow a systematic evaluation of the bacterial pathological effect (25). The ability of $F$. nucleatum to produce tissue damage in experimental animals is described in the literature (25-28). In this study, injection of F. nucleatum isolates affected the general health of the mice and produced weight loss and inflammatory or degenerative processes. It is interesting to note that $F$. nucleatum ATCC 10953 and ATCC 25586 were not pathogenic to Balb/c mice, whereas fresh clinical isolates of $F$. nucleatum were significantly more pathogenic than the controls. These isolates apparently expressed different virulence factors than the reference strains.

The lethality observed in F. nucleatum from human and animal origin was very similar. Histopathological alterations with inflammatory reaction and necrosis, observed in liver, suggest that liver can also offer nutritional and microenvironmental factors for the survival of $F$. nucleatum isolates and even production of liver damage, according to Abe et al. (29). On the other hand, the microbial migration suggests that microorganisms may possess virulence factors that might give protection during migration (25). After inoculation with human and animal isolates the surviving animals showed neither abscess production nor histopathological changes. The reason for this response remains unclear. However, research has recently focused on the role of host cell in the migration of stimuli produced by LPS (30).

Weight loss, inflammatory reaction, vascular congestion and microvacuolar degeneration in infected mice were due to toxemic or septic shock. However, the lack of coordinated movements in the posterior members of mice was due to vascular congestion with haemorragic areas and edema in the CNS, also associated to toxemic or septic shock.
Cell-free supernatants did not show lethality to animals, but produced weight or movements loss. However, heatinactivated bacteria were capable to kill mice, suggesting that a cellular component should be involved, e.g., LPS. In addition, our results suggest that fusobacterial LPS could have caused the lethal effect in mice. On the other hand, F. nucleatum possesses a potent LPS capable to induce cutaneous inflammatory reactions in rabbits (31), produces haemolysis (32) and has cytotoxic effects to L-929 and WI-38 cells (33). LPS is involved in pathogenesis of inflammatory reaction in mice, because it activates the complement system (34) or induces leukocyte migration (35). Others toxic substances produced by $F$. nucleatum, such as butyric and propionic acids or hydrogen sulfide, can also participate in tissue damage (57). Although, further information about the biochemistry of fusobacterial LPS or other metabolic products are necessary. In addition, the pathological effects of $F$. nucleatum on animal models, either in pure or mixed culture, may also be useful in immunological studies.

\section{ACKNOWLEDGMENTS}

We express our appreciation to Dr. Leonard W. Mayer for his critical suggestions, Ana Cláudia Okamoto for her collaboration and Thais Marques, Rosalia Regina de Luca, Andemir da Silva and João Paulo Ribeiro for their technical assistance. This work was supported in part by a FAPESP grant (Proc. No. 94/5784-7).

\section{RESUMO}

\section{Virulência de Fusobacterium nucleatum orais de primatas humanos e não humanos em camundongos}

Foi estudada a ação letal de 80 cepas de Fusobacterium nucleatum orais, isoladas de pacientes adultos com periodontite, indivíduos sadios e macacos Cebus apella, sobre camundongos isogênicos $\mathrm{Balb} / \mathrm{c}$. Os camundongos foram inoculados intraperitonealmente com cada inóculo bacteriano de aproximadamente $5 \times 10^{8} \mathrm{UFC} / \mathrm{ml}$. Todos os isolados clínicos induziram a perda de peso e dos movimentos coordenados. Além disso, foram observadas alterações patológicas no figado, SNC, coração e rins, mostrando reações inflamatórias ou congestão vascular. $61,2 \%$ dos isolados de $F$. nucleatum, provenientes de pacientes periodontais, $51,7 \%$ dos indivíduos sadios e $60 \%$ dos macacos foram capazes de matar camundongos em $48 \mathrm{~h}$. Os isolados clínicos foram significativamente mais patogênicos que F. nucleatum ATCC 10953 ou ATCC 25586. Também, B. fragilis ATCC 23745 mostrou-se letal contra os animais controle. Esses resultados sugerem que o LPS poderia estar envolvido nessa ação letal contra camundongos e poderia ter um importante papel na destruição dos tecidos ou na morte do animal. 
Palavras-chave: Fusobacterium nucleatum, patogênese, primatas humanos e não humanos.

\section{REFERENCES}

1. Rowland, M. D.; Delbene, V. E.; Lewis, J. W. Factors affecting antimicrobial susceptibility of Fusobacterium species. J. Clin. Microbiol., 25:476-479, 1987.

2. Finegold, S. M. Anaerobic Bacteria in Human Disease. $1^{\text {st }}$ Ed. New York: Academic Press, 1977.

3. Moore, W. E. C.; Moore, L. V. H. The bacteria of periodontal diseases. Periodontology 2000 5:66-77, 1994.

4. Rochford, J. Pleuropulmonary infection associated with Eubacterium brachy, a new species of Eubacterium. J. Clin. Microbiol., 12:722-723, 1980.

5. Claesson, R.; Edlund, M.; Persson, S.; Carlsson, J. Production of volatile sulfur compounds by various Fusobacterium species. Oral Microbiol. Immunol., 5:137-142, 1990.

6. Persson, S.; Edlund, M.; Claesson, R.; Carlsson, J. The formation of hydrogen sulfide and methyl mercaptan by oral bacteria. Oral Microbiol. Immunol., 5:195-201, 1990.

7. Bartold, P. M.; Gully, N. F.; Zilm, P. S.; Rogers, A. H. Identification of components in Fusobacterium nucleatum chemostat-culture supernatants that are potent inhibitors of human gingival fibroblast proliferation. $J$. Periodont. Res., 26:314-322, 1991.

8. Tuttle, R. S.; Strubel, N. A.; Mourad, J., Mangan, D. F. A non-lectin-like mechanism by which Fusobacterium nucleatum ATCC 10953 adheres to and activates human lymphocytes. Oral Microbiol. Immunol., 7:78-83, 1992.

9. Falkler Jr., W. A.; Hawley, C. A. Hemagglutinating activity of Fusobacterium nucleatum. Infect. Immun., 15:230-238, 1977.

10. Falkler Jr., W. A.; Smoot, C. N.; Mongiello, J. R. Attachment of cell fragments of Fusobacterium nucleatum to oral epithelial cells, gingival fibroblasts and white blood cells. Arch. Oral Biol., 27:553-559, 1982.

11. Ozaki, M.; Miyake,Y.; Shirakawa, M.; Takemoto, T.; Okamoto, H.; Suginaka, H. Binding specificity of Fusobacterium nucleatum to human erythrocytes, polymorphonuclear leukocytes, fibroblasts and HeLa cells. J. Periodont. Res., 25:129-134, 1990.

12. Xie, H.; Gibbons, R. J.; Hay, D. I. Adhesive properties of strains of Fusobacterium nucleatum of the subspecies nucleatum, vincentii and polymorphum. Oral Microbiol. Immunol., 6:257-263, 1991.

13. Ebersole, J. L.; Kesavalu, L.; Schneider, S. L.; Machen, R. L.; Holt, S. C. Comparative virulence of periodontopathogens in a mouse abscess model. Oral Dis., 1:115-128, 1995.

14. Haffajee, A. D.; Socransky, S. S. Microbial etiological agents of destructive periodontal disease. Periodontology 2000, 5:78-111, 1994.

15. Madden, T. E.; Caton, V. G. Animal models for periodontal disease. Meth. Enzymol., 236:106-119, 1994.

16. Schou, S.; Holmstrop, P.; Kornman, K. S. Non-human primates used in studies of periodontal disease pathogenesis: a review of the literature. $J$. Periodontol., 64:497-508, 1993.

17. Gaetti-Jardim Jr., E.; Zelante, F.; Avila-Campos M. J. Oral species of Fusobacterium nucleatum from human and environmental samples. $J$. Dent., 24:345-348, 1996.
18. Bennett, K. W. ; Duerden, B. F. Identification of fusobacteria in a routine diagnostic laboratory. J. Appl. Bacteriol., 59:171-181, 1985.

19. Summanen, P. H.; Baron, E. J.; Citron, D. M.; Strong, C.; Wexler, H. M., Finegold, S. M. Wadsworth Anaerobic Bacteriology Manual. 5th Edn Singapore: Star Publishing Company, 1993.

20. Avila-Campos, M. J.; Silva A. Pathogenic action of Actinobacillus actinomycetemcomitans on inbred strains of mice. Rev. Microbiol., 26:112116, 1995

21. Sundqvist, G. K.; Eckerbom, M. I.; Larsson, A. P.; Sjögren, U. T. Capacity of anaerobic bacteria from necrotic dental pulps to induce purulent infections. Infect. Immun., 25:685-693, 1979.

22. Clark, W. B.; Magnusson, I.; Abee, C.; Collins, B.; Beem, J. E.; McArthur W. P. Natural occurrence of black-pigmented Bacteroides species in the gingival crevice of the squirrel monkey. Infect. Immun., 56:2392-2399, 1988.

23. Holt, S. C.; Ebersole, J.; Felton, J.; Brunsvold, M.; Kornman, K. J. Implantation of Bacteroides gingivalis in non-human primates initiates progression in periodontitis. Science, 239:55-57, 1988.

24. Genco, C. A.; Arko, R. J. Animal chamber models for study of host-parasite interactions. Meth. Enzymol., 236:120-140, 1994.

25. Baumgartner, J. C.; Falkler Jr., W. A.; Beckerman, T. Experimentally induced infection by oral anaerobic microorganisms in a mouse model. Oral Microbiol. Immunol., 7:253-256, 1992.

26. Brook, I.; Walker, R. I. The relationship between Fusobacterium species and other flora in mixed infection. J. Med. Microbiol., 21:93-100, 1986.

27. Hill, G.B.; Osterhout, S.; Pratt, P.C. Liver abscess production by nonspore-forming anaerobic bacteria in a mouse model. Infect. Immun., 9:599603, 1974

28. Irving, J. T.; Socransky, S. S.; Tanner, A. C. R. Histological changes in experimental periodontal disease in rats monoinfected with Gram-negative organisms. J. Periodont. Res., 13:326-332, 1978.

29. Abe, P. M.; Lennard, E. S.; Holland, J. W. Fusobacterium necrophorum infection in mice as a model for the study of liver abscess formation and induction of immunity. Infect. Immun., 13:1473-1478, 1976.

30. Ishikawa, Y.; Kirikae, T.; Hirata, M.; Yoshida, M.; Haishima, T.; Kondo, S.; Hisatsune, K. Local skin response in mice induced by a single intradermal injection of bacterial lipopolysaccharide and lipase A. Infect. Immun., 59:1954-1960, 1991.

31. Sveen, K. The capacity of lipopolysaccharides from Bacteroides, Fusobacterium and Veillonella to produce skin inflammation and the local and generalized Shwartzman reaction in rabbits. J. Periodont. Res., 12:340350, 1977.

32. Falkler Jr., W. A.; Clayman, E. B.; Shaefer, D. F. Haemolysis of human erythrocytes by the Fusobacterium nucleatum associated with periodontal disease. Arch. Oral Biol., 28:735-739, 1983.

33. Horiba, N.; Maekawa, Y.; Abe, Y.; Ito M.; Matsumoto, T.; Nakamura, H.; Ozaki, M. Cytotoxicity against various cell lines of lipopolysaccharides purified from Bacteroides, Fusobacterium and Veillonella isolated from infected root canals. J. Endod., 15:530-534, 1989.

34. Nygren, H.; Dahlén, G.; Nilsson, L.A. Human complement activation by lipopolysaccharides from Bacteroides oralis, Fusobacterium nucleatum, and Veillonella parvula. Infect. Immun., 26:391-396, 1979.

35. Sveen, K. Rabbit polymorphonuclear leukocyte migration in vitro in response to lipopolysaccharides from Bacteroides, Fusobacterium and Veillonella. Acta Pathol. Microbiol. Scand., 85:375-380, 1977. 